\title{
Urban Seismomorphoses Seismic Vulnerabilities, an Embarrassing Legacy
}

\author{
Stephane Cartier* \\ Laboratory for Public Policies, Political Actions and Territories, National Council for Scientific Research \\ 14 bis rue Marie Reynouard 38100 Grenoble, France \\ Cloe Vallette \\ Laboratory for Public Policies, Political Actions and Territories \\ 14 bis rue Marie Reynouard 38100 Grenoble, France \\ cloe.vallette@unicaen.fr \\ Hafida Mediene \\ Laboratory for Geographic Spaces and Country Planning \\ Cité du Chercheur, EXIAP Locale du rectorat, Oran, Algeria \\ Received 16 December 2011 \\ Accepted 8 June 2012
}

\begin{abstract}
Seismic vulnerability challenges sustainable urbanism. Antioch, Manosque and Oran, three Mediterranean cities destroyed by earthquakes, demonstrate how preservation of urban patrimony protects populations. The methodological pattern "urban seismic patrimonial strategies" cross investment and patrimonial care to explain natural hazards mitigation as a factor of urban policy. Urban patrimonial managers are unaware to seismic threat, which obliges to explain liabilities. Buildings evolution observation indicates urban phases. According urban policy but without fatality, natural phenomena reshape urban morphology and amplify social vulnerability.
\end{abstract}

Keywords: Seismic Urbanism Patrimony Antioch Manosque Oran.

\section{Introduction}

Seismic collapses reveal anti-seismic gaps, the inequalities of vulnerability, the laxity of urban control, the shortcomings of protection, demographic imbalances, the dilapidation of buildings and hindrances to evacuation. These weaknesses create a variable urban vulnerability in time and space. Unequally distributed among districts (Vallette ${ }^{1}$, 2006), this vulnerability is also dynamic, showing how the uses of the city may develop. Thus certain urban sectors combine factors of risks linked to an industrial neighbourhood $\left(\mathrm{Beck}^{2}\right.$, 2006) while others hold major economic (Lutoff ${ }^{3}$, 2000 ; Cartier $^{4}$ 2004), administrative or institutional issues (D'Ercole, et al. ${ }^{5}$ 2005). A disaster adds a crisis into decision-making and an entanglement of materials,

*scartier@ujf-grenoble.fr bodies, activities and responsibilities to ordinary urban complexity (Hewitt ${ }^{6}, 1983$; Wisner, et al. $\left.{ }^{7}, 2004\right)$. In order to avoid chaos social sciences suggest a simplification of the urban decision-making process to prevent the tetanising anxiety about an unpredictable threat. In this way, the paper focuses on local manager as key-stakeholders.

After some synthetic efforts (Coburn and Spence ${ }^{8}$, 1992), different approaches and scales exist among the growing experiences of seismic vulnerability assessment according the site, the architecture type, the scale, the seismic scenarios, etc. (Benedetti, et al. ${ }^{9}, 1988$ ; Reiter ${ }^{10}, 1990$; Augusti, et al. ${ }^{11}$, 2001 ; Sepe, et al. ${ }^{12}$, 2008 ; Lantada ${ }^{13}$, 2009). To prognostic damage eventuality, four technical degrees are often used: single building examination in an architectural spirit (Zaçek ${ }^{14}$, 1996), calculation of ductility and retrofitting 
propositions by engineers for a type of building (with or without shaking table tests), identification of a clue point (the design, the age, the material, the roof) and statistical extrapolation with or without use of urban images (Gueguen, et al. ${ }^{15}$, 2008), statistical analyse according resistance of types of building (design, age, material) and urban density (Rojahn ${ }^{16}, 1986$; Wyss ${ }^{17}$, 2005).

Between singular building diagnosis to global overview of urban vulnerability and resilience capacity at universal scale, a middle scale approaches, by neighbourhood or by historical type, helps managers of ancient buildings to integrate safety standards according local geography and population interest to legacy. But these methods are confronted with some difficulties: monographic local approaches doesn't give elements to compare and class priorities; universal approaches are very generous but doesn't consider practical difficulties to implement (lack of data, level of expertise, time consuming, political disagreement); statistical overview of seismic loss assessment leads to un-efficient discourses; extreme simplification of technical criteria induces great disappointment of managers. Considering the rich literacy of methodology to assess building vulnerability, the missing point is how to get attention from local managers to the protection of patrimony and population, despite of financial cost of retrofitting and ... before improving disaster (Lavell ${ }^{18}$, 1994). Confronted with the long time return of seismic hazard, the interest of local managers needs to be stimulated with more ordinary preoccupations: people safety, housing, real estate rent, employment, economical growth, patrimonial proud, tourism impact, city image, community peace, personal interest, electoral triumph ... such as transform seismic safety policy into political ambition. Considering the risk situation as a political result, we propose to examine the vulnerability according a typology of urban management of patrimonial buildings, which directly gives information of potential danger for users and ruin of legacy.

On the whole technical sciences, social sciences and the authorities ask themselves about how to implement antiseismic policies. In this framework as for the restoration of the Qsûr (Ben Hounet and Guinand ${ }^{19}$ 2007), the renovation of dilapidated buildings is sensitive, as much from a technical point of view (consolidation, demolition, reconstruction) as from a political point of view (priority buildings, criteria, identity significance). The complexity of seismic vulnerability of old cities (Coburn and Spence $^{8}, 1992$; Lutoff ${ }^{3}, 2000$; Mouroux and Lebrun $^{20}$, 2006) leads to the analysis of their history, the diversity of uses and re-uses of buildings and the delicate financial issues $\left(\mathrm{Pico}^{21}, 2006\right)$. Understanding the fragility of old buildings, designed without anti-seismic engineering and badly maintained, requires knowledge on heterogeneous architectures (Gueguen et al. ${ }^{15}$, 2008; Leroi ${ }^{22}$, 2005). Mediterranean cities are particularly affected by this seismic situation imposed to inhabitants, real estate managers and civil service administrators.

In Istanbul, the 1999 earthquakes and the threat of tremors provoked variable reactions. Some anchor the protection of the heritage and of activities to the local civic life: the characterization of soils, the inventory of buildings, the census of vulnerable populations or even the analysis of rescue capabilities (Pérouse ${ }^{23}, 2006$ ). Some do not face up to the extent of the diagnosis and reinforcement work in apathy (Visier and Polo $\left.{ }^{24}, 2006\right)$. In the city of Cairo, after 1992, the vulnerability to earthquakes of some dilapidated districts enhances the constitution of peripheral private cities (Denis ${ }^{25}$, 2006). Carved in the stone of Mediterranean ruins and the memory of writings (Poursoulis et al. ${ }^{26}$, 2006), earthquake history leaves its mark on the urban architectural heritage, as much for monuments as for ordinary heritage. According to A. Le Blanc ${ }^{27}$ (2006), the collective architectural heritage inherits the marks of disasters. It represents a memory resource to guide a long-lasting protection. In this way, in Assisi, the partial collapse of the basilica in 1997 is a significant issue for the cohesion of the local community (Juilliard ${ }^{28}$, 2006). Following the same logic, but at international level, the reconstruction of the stronghold of Bam, an Iranian heritage classified by UNESCO, was at the origin of a strong commitment (AFPS ${ }^{29}$, 2004). The symbolic media coverage emphasizes the dilemma between a renovation of the heritage and the reconstruction of housing for the victims of the disaster (Juilliard $^{28}$, 2006).

Two themes emerge from this brief review of the vulnerability to earthquakes of Mediterranean cities: the local economic trend in the city (investment, 
speculation, needs for infrastructure, economic development) and the management of the architectural heritage (issues for identity and tourism). Despite local seismic specificities, a common logic influences the way the heritage should be preserved, left as is or deteriorated.

Anti-seismic safety yet falls within other factors of urban heritage management. Social, economic, political factors guide phases of maintenance against dilapidation, of investment or of abandonment at building, block, district, or city level. Urban phases combine decision-making cycles and physical (architectural and mechanical), economic and social transformations. Besides, the history and heterogeneity of districts shape each city. In addition to this problem, seismic safety requires simple criteria of selection, maintenance, abandonment or wait, to prioritize tasks. To avoid emotional, business or megalomania management of urban heritage financiers of programmes of international cooperation, national ministries, local elected representatives, architects, directors of town planning or heritage services expect a scientific, technical and organizational answer to their fundamental constraints: knowledge gaps, lack of availability, need for action, lack of financing, difficulty to express the arguments of a reasoned choice, responsibility of priorities...

To that end a simple analysis method of the issues and limits to the preservation of ancient buildings exposed to a seismic risk is applied for various Mediterranean cities that already were the victims of earthquakes: Manosque (France), Antioch (Turkey) and Oran (Algeria). Through the observation (field visit, photographic inventory, architectural typology, safety survey, mapping) of heritage practices (maintaining, transformation or reinforcement) and the analysis of decisions (public documents, codes, rules, professional recommendations and standards, interviews with city managers, real estate managers, landlords, inhabitants, patrimony protectors), the comparison distinguishes the local conciliation abilities between anti-seismic safety and heritage investment to understand the place of the anti-seismic criterion in the methods of heritage conservation. Based on field investigation, this empirical approach tries to confront declarations of managers and in situ observations to prognostic the transformation of urban shape exposed to seismic hazard according evident tendencies inscribed in urban patrimony management.

Contributions are to be in English. Authors are encouraged to have their contribution checked for grammar. American spelling should be used. Abbreviations are allowed but should be spelt out in full when first used. Integers ten and below are to be spelt out. Italicize foreign language phrases (e.g., Latin, French).

\section{Method and Fieldwork}

Focused on management of safety in old buildings, these analyse investigate three urban situations to indicate tendencies of local policy according simple criteria. This approach helps to characterize other situation, like Beirut (Lebanon) in order to mobilise local managers before the collapse. It represents only one point of global analyse of the urban system confronted to seismic hazard. In that way, the LIBRIS ${ }^{30}$ (Lebanon Risk Seismic) scientific program represents the next step of integration of geologic, architectural and human data.

The " urban seismic heritage strategies » analysis table (Table 1) matches the economic, often tourist, profitability of buildings with the maintenance logic of the architectural heritage (investments, uses, maintenance abilities). From a definition of the criteria decided with the heritage manager (contracting authority, public heritage manager, municipality, administrative institutions, international silent partners), the objective is to qualify the urban phases going along with key decision-making moments, which mark the development of buildings' dilapidation (first deterioration marks, mechanical effects, irreversible thresholds, acceleration of the ruin) in order to develop a common clarity on the state of buildings, the vulnerabilities, the opportunities and perspectives. As a source of dialogue between the actors concerned, this approach allows to progressively share the necessity for a protection of the heritage and the activities with the users and inhabitants: works, financing, rehousing and transfer of hazardous activities. Peculiar to each situation observed the management criteria however always imply that a diagnosis of physical elements (location, state of buildings, materials), of mechanical 
Table 1. Analysis Table: Urban seismic heritage strategies (typical factors)

\begin{tabular}{|c|c|c|c|c|c|}
\hline $\begin{array}{l}\text { Dilapidation/ } \\
\text { Threat }\end{array}$ & $\begin{array}{l}\text { Main } \\
\text { Vulnerability }\end{array}$ & Building maintenance & Financial Rentability & Urban Qualification & Urban Examples \\
\hline Earthquake & Owner & Yes / No & Yes / No & & \\
\hline Earthquake and rain & Inhabitants & Yes / No & Yes / No & & \\
\hline Earthquake and flood & Urban users & Yes / No & Yes & & \\
\hline Earthquake and war & Institutions & Yes / No & Yes / No & & \\
\hline
\end{tabular}

elements (development of materials under hydric and seismic strains) and of social elements (density of occupancy, types of use, demographic perspectives, economic resources, rehousing alternatives) be established. More than anything, with or without establishing a model, the matter is to report the possible developments with simple criteria in order to help managers choose a protection approach which should preserve the safety of the heritage, of the use and the user. Without a seismic hazard, dilapidation weakens buildings and technical maintenance mitigates vulnerability in particular for low magnitude earthquakes. This position leads to question the motivations of owners to invest and to question the decisions to implement public policies (regulations, investments, vocational training and information).

In 1708, the medieval centre of Manosque, near the Durance fault, was partly destroyed (Quenet ${ }^{31}$, 2005). After a quick reconstruction, some suburbs increased the urban pattern in the $19^{\text {th }}$ century (Angignard $^{32}$, 2005). After 1950, the establishment of the CEA in Cadarache and the settlement of rapatriates from Algeria increased the demographic impetus and urban extension (Angignard ${ }^{32}$, 2005). Industries (Géométhane, Géosel, CEA) make Manosque an attractive but vulnerable city. Heterogeneous constructions hinder the bringing up to standards by multiplying the parameters of diagnosis and reinforcement, all the more so as twelve buildings are listed as historical monuments $\left(\right.$ DRAC PACA ${ }^{33}$, 2008). And yet the ITER nuclear project attracts new populations. The need for housing and equipments conflicts with the limitation of building areas under prefectural surveillance. This restriction of the offer increases the price of land and intensifies urban density.
Antioch, the administrative centre of the Hatay province located in the southeast of the fault system of Anatolia is exposed to a high seismic risk. The long accumulation of seismic strains increases tension for this growing urban space $\left(\mathrm{APAME}^{34}\right.$ ). Following the destruction of the ancient city by an earthquake in 526, the medieval architectural heterogeneity diversified seismic vulnerability: densely populated narrow alleyways of the souk, composite constructions (cut stones, bricks, wood, concrete and metal), projecting stories over the streets, damage traces, ruins... Under the influence of Haussmann during the French mandate in Syria the avenues lined with cut stone and brick buildings encircled the medieval heart of the city. On the left bank, at the expense of the protective forest cover, unplanned contemporary urbanization clings to hills that are vulnerable to streaming, landslides and earthquakes. On the right bank the large avenues of the modern city structured by investments reduce the seismic threat.

As a prefectural administrative centre, Oran is the second economic city of Algeria with a demographic density of 10,676 inhabitants per $\mathrm{km}^{2}$ in 2006 (Oran Wilaya $^{35}$, 2006). Since it was founded in 903 AD, Oran has been marked by demolitions and reconstructions. The earthquake of October 1790 destroyed the main part of the Spanish heritage. During the reconquest of Oran in 1792, Bey Mohamed El Kabîr initiated the reconstruction of the city. Then French colonization (1830-1962) led the city to sprawl. After Independence, urbanization was an extension of the colonial period. The historical heterogeneity of constructions led to different phases of urban deterioration. The oldest districts host the biggest part of buildings in a bad state, or even ruined. Moreover from 1987 to 1995, despite numerous construction programmes, the housing crisis increased. The moderate earthquake of June 2008, the 
daily collapses during winter rains and the perspective of a great international congress in 2010 led the authorities to transfer the populations to the suburbs, to diagnose, demolish or restore the buildings.

Manosque, Antioch and Oran present different urban and social characteristics but were demolished and reconfigured by earthquakes. Failing to be maintained dilapidated buildings become dangerous while their users (inhabitants, tourists, shop employees, public services, architecture experts) expect a protection but fail to have the same adaptation abilities. The number and degree of dilapidation of the buildings require political choices of conservation to be made according to the available means (technical and financial) and to the needs of each population (reinforcing the sense of belonging, getting a source of income with tourism, maintaining urban coherence...). In order to understand how, why and to which extent each of those cities meets the challenge of the anti-seismic safety of old buildings, we propose a synthesis of researches fitting into various programmes (archeo-seismicity of APS in Manosque, anti-seismic protection of the monuments in Antioch and the prevention of the earthquake risk in Oran) by comparing information via the « urban seismic heritage strategies ».

\section{The Earthquake Risk: a Major Concern?}

The uncertainties in Manosque resulting from the experts' debates on the localization and direction of the Durance fault (Peulvast et al. ${ }^{36}$,1999) make the seismic hazard a suspicious subject. In this context, the urban constraints imposed by the $1997 \mathrm{PPR}^{37}$ (Risk Prevention Plan) relating to earthquakes carry a lot of weight. To support its consents and refusals of planning or development projects, the local council needs proven scientific results, in particular about the limits of unconstructible «strips » along "suspicious active seismic faults ». All the more so as the variety of local threats (soil movements, flooding, drought, forest fires, industrial installations) superimposes numerous standards. This superimposition is a constraint for public authorities and a source of anxiety for private investors. Urban planning then depends on a clarification of geological assessment and of administrative and legal interpretations.
In Antioch, the mobilization at school (rescue equipment on each floor, weekly «civil protection clubs», regular simulation exercises) and the activities of the Engineers Chamber (promotion of the antiseismic standards established in 2001 and control) show the seismic awareness. Benefiting from strong media coverage this mobilization promotes local solutions aided by the Turkish State. The new construction procedures include a study of soils, civil engineering calculations and architectural plans checked by a private controller, with a municipal agreement and paid for by the owner. According to engineers $70 \%$ of the new constructions comply with the 2001 paraseismic regulations, a success compared to the previous $40 \%$.

In Oran the dilapidation of the major real estate heritage is a direct danger to the population's daily life: «Oran still loses its old buildings one by one at a worrying pace and the spectre of victims haunts ancient buildings in the old districts of the city. As a reminder, during the last three years, Oran has recorded over 400 building collapses with some 1,200 families stricken. " (Oran Newspaper ${ }^{38}$ from August $7^{\text {th }}$, 2008).

The coastal natural hazards (storms, rains, flooding, landslides, earthquakes and the effects of corrosion) increase the mechanisms that ruin buildings in connection with a lack of maintenance. The quick deterioration of buildings increases urban vulnerability (135 collapses in 2003). Threatened by the slightest rain shower the population can not protect themselves against earthquakes. As a genuine warning shot the June 2008 earthquake in Oran confirms how much ordinary dilapidation is a constant vulnerability for precarious populations. Since 1997, in order to define areas of intervention, the Urban Development Plan (PDAU ${ }^{39}$, 1997) of Oran has listed the "deteriorated » constructions of the city: 528 buildings, i.e. 3,300 houses. The old districts (Sidi El Houari, El Derb and Saint-Antoine) concentrate half of these very populated collective buildings. The aging of ancient districts increases the housing shortage. Besides, following the colonial destruction of historical buildings, this ruined heritage implies preservation choices. Emergency or wild planning operations, started without any historical, architectural or archaeological awareness destroy entire districts, like the Calère district. 


\section{Desperate Times call for Small Measures}

\subsection{Architectural Heritage: which Profitability Criteria?}

The municipality of Manosque tries to reconcile the preservation of buildings, the needs for infrastructure ${ }^{40}$ and the constraining hazards by proposing to restructure the networks, to develop the city centre and to build collective equipment. According to the director of the mayor's cabinet and to the director of the municipal services, the renovation initiated in the 1970's represents a political showcase to reduce the desertion of the city centre (Saunier ${ }^{41}$, 2004). Certain salvaged buildings are reused as public equipment, others provide renovated housing. Despite the success achieved the results are mixed: dilapidation of buildings, lack of attractiveness and utility (Saunier ${ }^{41}$, 2004). The cost of renovations encourages the municipality to sell the heritage to private or mixed operators. The DRAC (Regional Direction of Cultural Affairs) however freezes the sales of listed historic buildings. Moreover few purchasers are able to accept the maintenance of buildings, the antiseismic safety and profitability. Finally the double supervision on certain buildings makes it difficult to share responsibilities. All these elements are in line with a difficulty to generate a process of preservation and development of the historical heritage which suggests a difficulty to integrate the anti-seismic safety of ancient, composite and little ductile buildings.

As a tourist asset and identity resource, the architectural heritage of Antioch also results from distinct interventions according to the listing status. Private homeowners favour their needs as users (housing, shops and workshops) over safety. Thereby old buildings are preserved to become tourist shops or hotels but others are modified for business needs regardless of the solidity of the structure. The fragmentation of responsibilities spreads investments. In a cave on a cliff the Saint-Pierre church is under the authority of the catholic bishop but the visit of this national heritage is under the state supervision of the Administration of Antiquities and Tourism. Places of worship are under a different supervision: the Direction of religious affairs for mosques under the authority of the Prime Minister, for imams are civil servants; private properties, parishes, dioceses, patriarchates for churches. Only in case of a denunciation the heritage commission controls the decisions made by property owner dioceses. Whatever their owner the majority of ancient monuments are protected by the Administration of Antiquities and Tourism of the State as a national heritage, as a symbol of national unity. The common administration of antiquities and tourism reflects the will to promote monuments as a cultural pillar for the tourist industry. The inventory of monuments determines the functions of each building, the rules of conservation and the price of the visit. The monuments should generate the means of their preservation but far from Istanbul's tourist godsend, the price of the visit does not make the isolated monuments of Hatay profitable, for they depend on State subsidies.

The development of the heritage also depends on contextual elements. Even if national regulations promote local investment in the anti-seismic safety of the heritage, the tourist potential is hindered by the distance to the airport. Besides, the safety of users is unequal. If the safety instructions and the vigilance of the guards protect the visitors of the colossal Titus tunnel, on the contrary the Citadel of the Crusaders of Antioch, listed in the national heritage without being a tourist site, is an accessible ruin laying itself open to a seismic threat. The transfer requires to clarify the responsibilities in terms of safety and anti-seismic reinforcement:

- Which criteria for heritage protection?

- Which experts should diagnose safety?

- Which seismic diagnoses?

Each question fuels shared competences between public entities while State intervention is now considered as a normal thing. Under the advice of Ministries (Ankara), the director of the museum of antiquities (Antioch) rather has the ordinary competence for the organization of mosaic exhibitions, the direction of the team and the cultural promotion of monuments. In case of an urgent problem the director requests a technical inspection to the State Administration for the Inspection of Buildings (Adana) which will assess safety, decide on investments and choose the contracting company. But there, remains a global concern about traditional know-how disappearing for instance for the roof structure of wooden houses. Programmes of urban restoration favour a romantic preservation of the heritage. But restoration techniques can involve seismic mitigation as the care provided for the safety of listed monuments in 
the Turkish heritage shows.

In Oran, two programmes show the issues of the renovation of ancient buildings. From 1997, the PDAU assessed that « In 1987, more than $80 \%$ of houses were over 25 years of age and even if the current construction impetus was maintained the number of houses over 50 years of age by 2015 would represent more than $45 \%$ of the whole estimated stock. " (PDAU $\left.{ }^{38}, 1997: 193\right)$. In March 2008, before the renovation works started, the Office for Real Estate Promotion and Management (OPGI) of Oran listed 1,990 buildings requiring « imminent intervention » $\left(\mathrm{OPGI}^{42}\right.$, 2008). The financial limits of OPGI require selecting the buildings according to their architectural interest and their visibility, in order to improve the city's image and encourage the neighbouring owners. Focused on 200 buildings in the historical districts this subjective strategy favours heritage and tourist promotion. In addition the European cooperation programme ARCHIMEDES $S^{43}$ applied to four Mediterranean cities (Beirut, El Mina, Istanbul, Oran) promotes the transfer of competences for urban renovation to develop the heritage and sustainable tourism. In Oran this project applies to the Sidi El Houari district, the old city centre that has become a neglected transit district. Relying on the Architecture and Beaux-Arts schools the objective is to reintegrate this district into the city by teaching specialists the techniques of heritage restoration and conservation, of heritage inventory, by developing a work plan, renovating a building, planning other renovations in partnership with public developers. If the primary function of housing is to protect people a state of ruin remains a disaster. Urban pauperization goes beyond any aesthetic concern and turns the central districts into very hazardous ruins for the inhabitants and activities (shops, markets) traumatized by the threat of the lightest rain. Discontent and disappointment are such that even efficient rehousing operations go through tension and require massive police interventions to prevent riots. If « (...) the heritage policies can be tools for the management of the seismic risk.» (Le Blanc ${ }^{27}$, 2006:246), the contribution of Oran projects is indirect by the involvement of safety in the political agendas, favoured in emergency by the prospect of an international congress of the gas industry in 2010. This sudden urban awareness goes along with luxurious intentions made of Saudi investments with a Korea- inspired model... Between an anarchic concreting and the mirages of the "city of the sea ", the suburban growth leaves the popular city centre behind. Pedagogically concentrated on an exemplary building the method of the ARCHIMEDES ${ }^{43}$ programme suggests protecting the district of Sidi El Houari with a will to preserve its architectural aspect. Vividly the programme plans to eradicate the already ruined buildings or the ones that could possibly collapse. If the ambition is to really transfer to Oran a methodology of urban regeneration favourable to the economic development and the tourist promotion of the cultural heritage, nothing on the other hand seems to indicate a specific attention to the local natural threats.

\subsection{Urban Decentring: which Efficiency?}

In Manosque, the issue of the city centre and the needs for equipment drive the municipality to build new public buildings (hospital, schools) outside the historical defensive walls. This strategy is common: «The cost of the compliance to standards of heritage buildings and needs for surfaces have led the companies to look for locations outside «historic» spaces of city centres and ancient suburbs. » (Garat, Gravari-Barbas and Veschambre ${ }^{44}$, 2008: 6). The new buildings then respect all the safety standards, of which anti-seismic standards. However, outside, they separate activities and ignore the revitalization of the historical centre.

In Antioch, the fragility of the old city clashes with the efforts of seismic safety in other districts. Yet, despite real estate conflicts and the abuse of sea sand in the constructions, the demolition of hazardous buildings allows to reconstruct private new housing complying with the 2001 seismic codes, however without any concern for homogeneity in the historical style. The difference of intervention according to districts is then essentially linked to the heritage value of the old city.

In Oran, the geographical transfer, particularly marked towards the east, generates new tower districts with collective housing succeeding the individual detached houses of the suburbs. Urban programmes involve the demolition of ruined housing and the rehousing of inhabitants : " The planning policy is centred upon the production of new housing in the suburbs to the detriment of an urban centre that deteriorates alarmingly. » $\left(\mathrm{OPGI}^{42}, 2008:\right.$ 1). Favoured by the « 1 
Million Houses» presidential plan (2004-2009), these rehousing programmes are slowed down by construction problems, the difficulties to establish fair lists of beneficiaries, slow decision-making and experts' meticulousness. Besides, these programmes increase with a list of new disaster victims as new crises, exceptional seismic tremors (June 2008) or ordinary autumn rains dictate. Through lack of money inventories are just the initial step of programmes that are announced but rarely achieved. Socially the objective is to simultaneously carry out the rehousing of hundreds of families as during summer 2008 and to commit the population into transforming the districts. A rare initiative in Algeria, inhabitants' associations invited to the international symposium on urban revitalization try to get informed and to spread the projects (autumn 2008). They gather inhabitants threatened by the collapse of their houses, inhabitants waiting for architectural restoration and owners. The commitment of real estate owners is still hard to achieve due to the unclear real estate status of inhabitants. Far from being rural squatters fleeing terrorism the resident families have often settled for a long time in the districts, at least since Independence. Very often born in the buildings or in the neighbourhood, the inhabitants hold certificates of occupancy and not property certificates. In the absence of clear criteria for public rehousing, the tenants who give up paying the rents for ruins and legatees without property certificates, the rehousing lists exclude a large population coming from ancient districts to the benefit of real estate speculators.

\subsection{Suspense}

In Manosque, the pro-active renovation of the city centre places the seismic and heritage question on the municipal agenda. Nevertheless, administrative difficulties, the deterioration of buildings, heritage listing and the renovation costs involved by restricting standards, both anti-seismic and aesthetic, make the task heavy. The strategies of transfer of responsibilities and spatial transplantations throw a city already lacking expansion off balance. Besides the identity issue of the city centre is not reinforced by a tourist, commercial or political economic profitability which increases the municipal debt. As an urban showcase the effort of cultural development of the heritage has no immediate profitability despite the past choices of the municipality to purchase historical buildings.
In Antioch, profitability encourages heritage maintenance. The anti-seismic effort promotes the tourist potential without the collapse issue. However the slow pace of profitability slows down the anti-seismic reinforcement of urban monuments. Under the supervision of the Culture and Tourism Ministry, the Direction of Heritage and Museums comes to a compromise with archaeologists, Art historians, town planners, lawyers and municipalities without experts on seismic safety. The Direction monitors restoration projects without relying on a surveillance organization. Always delicate in case of an anti-seismic reinforcement the restoration can lead to a denunciation and judicial proceedings. Facing this situation and the multiplicity of supervision authorities for worship places, the Turkish State plans to transfer some monuments to local authorities which raise the question of their ability to finance studies, to set up a conservation policy, to organize visits and safety measures, to produce expertise, works and control. Indirectly insurance companies could become the managers of historical buildings protection, of tourist development and of investment safety.

Oran suffers from a disastrous lack of maintenance and from the chronic weakness of the urban project for the historical heritage. After the current phase of ruins the tragic state of dilapidation naturally leads to a phase of speculative reinvestment through a complete renewal of buildings and populations. However the international involvement in a programme to salvage the heritage mitigates this destiny and provides for an opportunity of tourist promotion while preserving the façade urban identity. Breaking the deadlock requires means. As a historical opportunity the public authorities have the petrodollar financial godsend at their disposal to end the deadlock and the auspicious ARCHIMEDES ${ }^{43}$ international cooperation. In the framework of the " 1 Millions houses» programme (2004-2009), the construction of hundreds of social houses in Oran suburbs provides for a solution to the victims of a disaster. But the mobilization of means remains complex. In Algeria, heritage protection remains the subject of paradoxical virulent political injunctions and of a tangible administrative laxity. Governments succeed one another, the national heritage passes away. 


\section{Conclusion}

In the context of Mediterranean transformations, the maintenance of a world heritage requires to realistically admit contemporary social, economic and political tensions. If the heritage deserves an honorary place, economic transitions tend to ignore it due to its low profitability. Little useful to provide accommodations to populations, ancient buildings bother real estate speculators always tempted by the tabula rasa or a « Neapolitan-like » façade monopolizing (Montesano ${ }^{45}$, 2003). Confronted with an anarchic urbanization the public authorities hardly place the protection of monuments, a fortiori against a ghostly seismic threat, on their agendas and budgets. As a now classical solution for ancient cities tourist promotion nevertheless requires an effort of seismic mitigation.

All the more so relevant that it is easily readable for managers the «Urban seismic heritage strategies» (Table 2) matches investments and the protection of the heritage to select renovation policies in the light of natural risks. The information gathered characterize urban vulnerabilities and renovation efforts: interests of investments (maintenance, profitability, speculation), of the heritage remain scarce and limited. Renovation efforts must however methodically integrate the adaptation to seismic conditions to all the phases of the architectural or urban project (Cartier and ElAssad ${ }^{46}$, 2010). To reconcile the protection of the heritage and the safety of users it is then essential to identify which item requires the most safety and why. Understanding their motivations helps prioritize the means according to safety objectives, financial resources, acceptable responsibilities and local abilities.

Stabilizing real estate and land statuses is the first step to prevent a ruining of the heritage through the harmful joint ownership between private or public joint owners. Even if the necessary cost for an anti-seismic renovation excludes investments from the poorest people, involving inhabitants into the project and sharing the benefits of tourism are a guarantee for a further maintenance of the heritage.

Hope of community involvement supposes the capacity of leaders to be proud of the heritage and aware of danger. Inhabitants confronted with all year long collapses, for example in Oran, express directly their

Table 2. Urban seismic heritage strategies

\begin{tabular}{llllc}
\hline $\begin{array}{l}\text { Dilapidation/ } \\
\text { Threat }\end{array}$ & $\begin{array}{l}\text { Main } \\
\text { Vulnerability }\end{array}$ & Building maintenance & Financial Rentability & Urban Qualification \\
\hline Earthquake & Owner & Yes & No & Cultural promotion \\
Earthquake and rain & $\begin{array}{l}\text { Inhabitants } \\
\text { Urban Users }\end{array}$ & No & No & Ruin \\
Earthquake and flood & $\begin{array}{l}\text { Inhabitants } \\
\text { Owners } \\
\text { Earthquake and war }\end{array}$ & Yes & Yes & Investment \\
& Institutions & No & Yes & Lantioch speculation \\
\hline
\end{tabular}

tools for public policies (regulation, subsidies, training, information), links between real estate interests and protection policies, decision-making process (abandonment/freezing of the heritage, safety promotion, urban renewal).

The developments in the degradation of buildings (first deterioration marks, mechanical effects, irreversible thresholds, acceleration of the ruin) show the cycles of urban decisions, arrangements of political initiatives and of private opportunities. By increasing vulnerability natural events mark the development and morphology of a city but are absolutely not inevitable. The opportunities for a symbolic and financial reinvestment fear and needs by reclaiming retrofitting or new homes. The general tendency of decrease of density in historic vulnerable quarters leads to push people and activities outside historical perimeter in suburbs. But central historical quarters represent also some amenities and resources (familial and community ties, employment facilities, trade opportunities, education and health services). Settling on dangerous housing is also a mean to keep rights on land ownership, real estate speculation in city, reclaim for new housing.

More than techniques, energies must be devoted to a dialogue between actors so as to understand safety objectives, available means, acceptable constraints and 
agendas. But thinking in terms of « negotiated » risk requires thinking on the temporality of the project to reduce the vulnerability of ancient buildings with a view towards sustainable tourism. In this framework seismic safety can be supported by heritage policies. This strategy allows to associate the symbols of collective identity with the protection of the users of monuments.

\section{References}

1. C. Vallette, Et Chaque Année, au retour des pluies..., (Master Thesis, Lyon II University, Lyon, France, 2006).

2. E. Beck, Approche multi-risques en milieu urbain, Application à l'agglomération de de Mulhouse (HautRhin) (PhD Thesis, Geography, Louis Pasteur University, Strasbourg, France, 2006).

3. C. Lutoff, Le système urbain niçois face à un séisme. Méthode d'analyse des enjeux et des dysfonctionnements potentiels, (PhD Thesis, Geography, Savoie University, Chambéry, France, 2000).

4. S. Cartier, Contraintes sismiques et décisions économiques: de la crise à la réduction de la vulnérabilité, Revue du Service Géologique de l'Algérie, 12 (2004) 193-204.

5. R. D'Ercole, P. Metzger and N. Bermudez Arboleda, Espaces enjeux, espaces vulnérables. Le cas de Quito (Equateur), Systèmes d'information géographique et gestion des risques, (2005) 16-19.

6. K. Hewitt, The Idea of Calamity, in The Technocratic Age in Interpretations of Calamity: from the viewpoint of human ecology (Allen and Unwin, London,1983), pp. 332.

7. B. Wisner, P. Blaikie, T. Cannon and I. Davis, At Risk, natural hazards, people vulnerability and disasters, (Routledge, Oxon, 2004 [1994]).

8. A. Coburn and R. Spence, Earthquake Protection, (Wiley, Chixhester, 1992).

9. D. Benedetti, G. Benzoni, and M.A. Parisi, Seismic vulnerability and risk evaluation for old urban nuclei, Earthquake Engineering \& Structural Dynamics, Vol.16 num.2 (1988) 183-201.

10. L. Reiter, Earthquake and hazard analysis - Issues and Insights, (Columbia University Press, New York. 1990).

11. G. Augusti, M. Ciampoli and P. Giovenale, Seismic vulnerability of monumental buildings, Structural Safety, Vol.23 num. (2001) 253-274.

12. V. Sepe, E. Speranza and A. Viskovic, A method for large-scale vulnerability assessment of historic towers, Structural Control and Health Monitoring, 15 (2008) 389-415.

13. N. Lantada, L.G Pujades and A.H Barbat, Vulnerability index and capacity spectrum based methods for urban seismic risk evaluation. A comparison, Natural hazards, 51 (2009) $501-524$.
14. M. Zacek, Construction parasismique : risque sismique, conception parasismique des bâtiments, Réglementation, (Editions parenthèses, Arles, France, 1996).

15. P. Gueguen, C., Lutoff, P.A., Davoine, G., Talierco, F., Cotton and S. Cartier, Analyse de la vulnérabilité sismique dans un pays à sismicité modérée: le cas de Grenoble, Actes du colloque «Vulnérabilités sociétales, risques et environnement, comprendre évaluer» (Toulouse, France, 2008).

16. C. Rojahn, R.L Sharpe, R.E Scholl, A.S Kiremidjian, R.V Nutt ans R.R Wilsan, Earthquake damage and loss evaluation for California, Earthquake spectra, Vol.2 num.4 (1986) 767-782.

17. M. Wyss, Human losses expected in himalayan earthquakes, Natural hazards, 34 (2005) 305 - 314.

18. A. Lavell, Opening a Policy Window : The Costa Rican Hospital Retrofit and Seismic Insurance Programs 19861992, International Journal of Mass Emergencies and Disasters, Vol.12 num.1 (1994) 95-115.

19. Y. Ben Hounet and S. Guinand, La restauration des qsûr : institution du patrimoine et enjeux de mémoire, Espaces et Sociétés, 128-129 (2007) 151-170.

20. ${ }^{*}$ P. Mouroux et B. Le Brun, Presentation of "RISK-UE Project”, Bulletin of Earthquake Engineering, 4(4) (2006) 323-339.

21. L. Pico, Géographie et assurance: le risque sismique dans les espaces urbains mal documentés: le cas de Beyrouth ((PhD Thesis, Geography, Sorbonne University, Paris, France and Saint-Jospeh University, Beyrouth, Libano, 2006).

22. E., Leroi, Réalisation d'une étude sur les critères pour la définition de mesures de réduction du risque sismique du bâti existant en France, (URBATER, Ministère de l'Écologie et du développement durable, France, 2005).

23. J-F, Pérouse, Catastrophes, risques sismiques et redécouverte de la dimension locale à Istanbul, in Pouvoirs urbains et sociétés urbaines face aux risques, sur le pourtour de la Méditerranée (AnthroposEconomica, Paris, 2006), pp. 56-78.

24. C. Visier and J.F. Polo, Les séismes de 1999 en Turquie, un laboratoire de la société civile, in Pouvoirs urbains et sociétés urbaines face aux risques, sur le pourtour de la Méditerranée (Anthropos-Economica, Paris, 2006), pp. 79-98.

25. E. Denis, Risque et actualisation de l'écologie métropolitaine : la figure emblématique des citées privées au Caire, in Pouvoirs urbains et sociétés urbaines face aux risques, sur le pourtour de la Méditerranée (Anthropos-Economica, Paris, 2006), pp.168-195.

26. G. Poursoulis, A. Levret, N. Lambert, A. Rideau and B. Helly, The 1708 Manosque earthquake (France): A reading of its archaeological traces as a contribution to estimate the effects on buildings, Journal of Seismology, 10 (2006) 511-526.

27. A. Le Blanc, Les politiques de conservation du patrimoine urbain comme outils de gestion du risque sismique. Trois exemples en Italie : Noto, Assise, Gémone 
(PhD Thesis, Geography, Provence University, AixMarseille, France, 2006).

28. C. Julliard-Macian, Le tremblement de terre d'Assise du 26 septembre 1997, ou l'écriture d'un drame parfait in in Pouvoirs urbains et sociétés urbaines face aux risques, sur le pourtour de la Méditerranée (AnthroposEconomica, Paris, 2006), pp. 33-55.

29. AFPS, Le séisme de Bam, Iran, du 26 décembre 2003 (Association Française du Génie Parasismique, Paris, 2004).

30. LIBRIS, Contribution à l'étude du risque sismique au Liban (ANR, Paris, 2009).

31. G. Quenet, Les Tremblements de terre aux dix-septième et dix-huitième siècles. La naissance d'un risque (Édition Champ Vallon, Seyssel, France, 2005).

32. M. Angignard, La perception du risque sismique en Provence, Exemple de collégiens à Manosque, (Master Thesis, Paul Valery University, Montpellier, France, 2005).

33. DRAC PACA, Immeubles et Jardins en Provence-AlpesCôte-d'Azur, (Ministère de la culture et de la communication, France, 2008).

34. APAME Programme APAME (Programme Européen) : The Impact of Large Earthquakes on the Archeological Sites and Cultural Heritage in west Syria and Lebanon, M. Meghraoui (dir.)

35. Oran Wilaya, Directory of Oran wilaya, (Oran Wilaya, Algeria, 2006).

36. J-P. Peulvast, E. Baroux, O. Bellier ans M. Sébrierlien, Le problème de l'activité des failles de Nîmes, de SalonCavaillon et de la moyenne Durance (SE de la France) : apports de la géomorphologie structurale, Géomorphologie, 5-4(5) (1999) 327-358.

37. Manosque Municipality, Fiche synthétique sur les risques recensés (Risk Prevention Plan's extract approved by prefect, April 24th 1997, 2005).

38. J. Boukraâ, Oran : Un enfant de 11 ans tué dans un effondrement, Quotidien d'Oran (Oran Newspaper from August 7th 2008).

39. PDAU Oran, Plan Directeur d'Aménagement et d'Urbanisme (PDAU) du groupement d'Oran, (Wilaya Oran, Oran, Algeria, 1997).

40. National Institute for Statistic and Economic Studies, Schéma de Cohérence territoriale (SCOT) de la région de Manosque, région Provence Alpes Côtes d'Azur (National Institute for Statistic and Economic Studies, France, 2005).

41. P. Saunier, Manosque, Alpes de Haute-Provence, Actualisation du plan de référence du centre historique (Ville de Manosque / Urb’Action, Marseille, France, 2004).

42. OPGI Oran, Rapport de Présentation, Opération de réhabilitation de 200 imeubles à Oran (Ministère de l'Habitat et de l'Urbanisme, Office de Promotion et de Gestion Immobilière d'Oran, Département Développement de la promotion immobilière et Foncière et de Réhabilitation, Algeria, 2008).
43. ARCHIMEDES (Actions to Regenerate Cities and Help Innovative Mediterranenan Economic Development Enhancing Sustainability), Newsletters (EuroMed, Eurpoean Union), 1/2/3 (2007-2008).

44. I. Garat, M. Gravari-Barbas and V. Veschambre, Préservation du patrimoine bâti et développement durable: une tautologie ? Les cas Nantes et Angers ", Développement durable et territoires, 4 (2008) URL : http://developpementdurable.revues.org/4913.

45. G. Montesano, Di questa vita menzognera, (Universale Economica Feltrinelli, Milan, 2003).

46. S. Cartier and K. ElAssad, Enjeux et procédures de protection sismique du patrimoine historique, la réhabilitation des Ex-Galeries de France en Musée d'Art Moderne d'Alger, Annales de la Recherche Urbaine, 106 (2010) 171-178. 